\title{
Parasites of ornamental fish commercialized in Macapá, Amapá State (Brazil)
}

\author{
Parasitos de peixes ornamentais comercializados em Macapá, Estado do Amapá (Brasil) \\ Érico de Melo Hoshino ${ }^{1}$; Maria Danielle Figueiredo Guimarães Hoshino ${ }^{1}$; Marcos Tavares-Dias ${ }^{2 *}$ \\ ${ }^{1}$ Universidade do Estado do Amapá - UEAP, Macapá, AP, Brasil \\ ${ }^{2}$ Empresa Brasileira de Pesquisa Agropecuária - EMBRAPA AMAPÁ, Macapá, AP, Brasil
}

Received October 18, 2017

Accepted January 10, 2018

\begin{abstract}
This study investigated the parasites fauna of four freshwater ornamental fish species in aquarium shops of Macapá, Amapá State, in addition to survey the commercialized fish species and sanitary conditions of aquarium shops. Different native and non-native ornamental fish species were found in aquarium shops, mainly Poecilidae. We examined 30 specimens of Xiphophorus maculatus, 30 Danio rerio, 30 Paracheirodon axelrodi, and 30 Corydoras ephippifer for parasites. Of the 120 fish examined, $22.5 \%$ were parasitized by one or more species and a total of 438 parasites were collected and identified. Parasites such as: Ichthyophthirius multifliiis, Monogenea, undermined Digenea metacercariae, Acanthostomum sp. metacercariae, Camallanus spp., Bothriocephalus acheilognathi and Echinorhynchus sp. infected the hosts examined. Endoparasites in the larval stage showed the greatest diversity and Camallanus spp. was found in all hosts species examined. Paracheirodon axelrodi (43.3\%) was the most parasitized host, while C. ephippifer (6.7\%) was the least parasitized. Despite the low ectoparasites level, six species of endoparasites was observed, demonstrating that prophylactic and quarantine procedures were not fully adequate. Therefore, failures in prophylactic procedures on any link in the production industry of ornamental fish may cause parasite transmission to ornamental fish captured in different environments and localities.
\end{abstract}

Keywords: Culture, ornamental fish, parasites, sanity.

\section{Resumo}

Este estudo investigou a fauna de parasitos de quatro espécies de peixes ornamentais de água doce comercializadas em lojas de aquários de Macapá, estado do Amapá, bem como as espécies de peixes comercializadas e as condiçôes sanitárias dessas lojas. Diferentes espécies de peixes ornamentais nativos e não nativos foram encontradas em lojas de aquários, principalmente Poecilidae. Foram examinados 30 espécimes de Xiphophorus maculatus, 30 Danio rerio, 30 Paracheirodon axelrodi e 30 Corydoras ephippifer, para análise de parasitos. Dos 120 peixes examinados, 22,5\% estavam parasitados por uma ou mais espécies de parasitos. Foram coletados um total de 438 parasitos tais como: Ichthyophthirius multifiliis, Monogenea, metacercárias de Digenea não identificadas, metacercárias de Acanthostomum sp., Camallanus spp., Bothriocephalus acheilognathi e Echinorhynchus sp. A maior diversidade foi de endoparasitos em estágio larval e Camallanus spp. foi encontrado em todas as espécies de hospedeiros examinados. Paracheirodon axelrodi (43,3\%) foi o hospedeiro mais parasitado, enquanto C. ephippifer (6,7\%) o menos parasitado. Apesar do baixo ectoparasitismo, foram encontradas seis espécies de endoparasitos, demonstrando que os procedimentos profiláticos e a quarentena não foram adequados. Portanto, falhas nos procedimentos profiláticos em qualquer elo da cadeia produtiva de peixes ornamentais pode causar riscos de transmissão de parasitos para peixes de diferentes ambientes e localidades.

Palavras-chave: Cultivo, peixe ornamental, parasitos, sanidade.

\section{Introduction}

Ornamental fish keeping is one of the most popular hobbies around the world and has resulted in a turnover of US\$ 100 billion in 2015 , and continues to grow annually (ABIDI et al., 2011; FARIA et al., 2016).

*Corresponding author: Marcos Tavares-Dias. Empresa Brasileira de Pesquisa Agropecuária - Embrapa Amapá, Rodovia Juscelino Kubitschek, no 2600,

Km 5, CEP 68903-419, Macapá, AP, Brasil. e-mail: marcos.tavares@embrapa.br
In Brazil, ornamental fish keeping is a very important sector and this endeavor generated an income of US\$ 16.7 billion in 2014 (FARIA et al., 2016). Ornamental fish are a significant source of income for many riverine communities from the Amazon basin and aquaculture ventures elsewhere in Brazil. More than $90 \%$ of the freshwater ornamental fish sold in Brazil are bred in captivity (SOMMERVILLE et al., 2016; FARIA et al., 2016). However, the 
local trade and export of ornamental fish by Brazilian aquaculture ventures has been inhibited by poor quality and the lack of a regular production process. Singapore is the largest exporter of ornamental fish followed by the Spain and Japan, while Brazil ranks eighth in exports with US \$ 13.5 million (FARIA et al., 2016). Although the ornamental fish industry in Brazil has great potential for growth and development, one of the weakest links is a complete lack of understanding of the different diseases that affect ornamental fish farming.

The recent development of ornamental fish industry, not only for export, but also for domestic supply, has attracted the attention of researchers and interested enterprises. Thus, aquaculture and the propagation of ornamental fish are sectors that have increased during recent decades in Brazil. Brazilian ornamental fish are acknowledged around the world for their beautiful appearance, their small size, and easy maintenance. It is widely recognized that the transport of ornamental fish may cause the spread of pathogens and diseases from one country to another (ALVES et al., 2000; ABIDI et al., 2011; MEHRDANA et al., 2014; SALGADO-MALDONADO et al., 2015), and this is due to a great extent in faulty sanitary management. However, the manifestation of these diseases occurs only when the parasites have favorable situations for their proliferation. These conditions tend to be: environmental stress, poor culture conditions, inadequate transportation, stocking density, and poor nutrition (PIAZZA et al., 2006; TAVARES-DIAS et al., 2009; GARCIA et al., 2009; TAVARES-DIAS et al., 2010; ABIDI et al., 2011; MARTINS et al., 2012; MOYSES et al., 2015). The inadequate sanitary management conditions cited above can cause economic losses and frustration among producers. In addition, diseases in ornamental fish has a particular importance because it may cause discoloration, change of body shape, and decreased growth, any of which may compromise their trade value.

Knowledge about diseases affecting ornamental fish and the parasites that infect them is crucial for success in the ornamental fish industry. Many of the economic losses occurring in the aquarium industry are generally caused by protozoan and metazoan species. Some ectoparasites, especially Ichthyophthirius multifiliis Fouquet, 1876, Trichodina spp. and monogeneans (PIAZZA et al., 2006; TAVARES-DIAS et al., 2009; GARCIA et al., 2009; KOYUNCU, 2009; MOYSES et al., 2015), are found infecting ornamental fish species. Parasitic diseases are harmful and pose limiting factors in the rearing of ornamental fish. Nevertheless, several parasitological surveys (ALVES et al., 2000; PIAZZA et al., 2006; TAVARES-DIAS et al., 2009; KOYUNCU, 2009; GARCIA et al., 2009; MEHRDANA et al., 2014; MOYSES et al., 2015; FLORINDO et al., 2017) have been performed on freshwater ornamental fish and these studies verify a very diverse set of parasitic species. However, none of these surveys include aquarium fish cultured in the State of Amapá, (Brazil). Thus, the purpose of this study is to survey the parasites infecting Xiphophorus maculatus Günther, 1866, Danio rerio Hamilton, 1822, Paracheirodon axelrodi Schultz, 1956 and Corydoras ephippifer Nijssen, 1972, which are commercialized in aquarium shops in Macapá, Amapá State. It is also very important to investigate the farmed ornamental fish species and whether management or environmental conditions are responsible for the parasites found in these hosts.

\section{Materials and Methods}

\section{Characteristics of the aquarium pet shops and their sanitary conditions}

In the aquarium shops, each fish ornamental species are maintained in different aquarium of $100 \mathrm{~L}$, and in different stocking densities. The fish are fed daily with ration for ornamental fish. The management practices adopted by the aquarium shops $(n=6)$ of Macapá, Amapá (northern Brazil) were investigated through survey interviews focused on activity time, traded fish species, quantity traded monthly, fish suppliers, water quality parameters (temperature, $\mathrm{pH}$, conductivity, turbidity, dissolved oxygen and salinity), fish mortality, health problems, and management techniques (quarantine, prophylaxis and antiparasitic treatment).

\section{Collection of fish and parasite analysis procedures}

In October of 2015, 30 specimens of $X$. maculatus, 30 P. axelrodi, 30 C. ephippifer, and 30 D. rerio found in aquarium shops in Macapá were collected for parasitological analysis. All fish were transported to the Laboratory of Embrapa Amapá to be analyzed. This study was developed in accordance with the principles recommended by the Brazilian College of Animal Experimentation (COBEA) and with the authorization from Ethics Committee in the Use of Animal of the Embrapa Amapá (Protocol: 005 - CEUA/CPAFAP).

Each fish was measured in length $(\mathrm{cm})$ using a caliper and then they were necropsied to examine the gills to collect ectoparasites, and then to examine the gastrointestinal tract for collection of endoparasites. The fish gills were removed and analyzed under a microscope, and the gastrointestinal tract with a stereomicroscope. The parasites found were fixed in formalin 5\%, preserved in $70 \%$ ethyl alcohol, quantified, and stained for identification (EIRAS et al., 2006). The ecological terms adopted are those suggested by Bush et al. (1997).

\section{Results}

In the aquarium shops investigated in this study, 17 native fish species are marketed along with non-native ornamental fish (Table 1). There are fourteen aquarium shops in Macapá, and it is estimated that combined, they sell about 10,000 ornamental fish per month. The existence time and duration of these aquarium shops in the market varies from 3 to 30 years. In general, non-native fish are purchased from fish farms originating in the states of São Paulo, Rio de Janeiro, Ceará and/or Pernambuco (Brazil). Native fish species are captured from ornamental fishing areas in the Amazon basin and Amapá State.

In the aquarium shops investigated in this study, the mean temperature of the aquariums was $30.6 \pm 0.4^{\circ} \mathrm{C}, \mathrm{pH} 8.0 \pm 0.5$, electric conductivity $1.02 \pm 0.98 \mu \mathrm{s} / \mathrm{cm}$, dissolved oxygen $3.8 \pm 1.1 \mathrm{mg} / \mathrm{L}^{-1}$, salinity $0.52 \pm 0.51 \mathrm{ppt}$, and turbidity 0 NTU.

Mortality of ornamental fish in aquarium shops and that of their clients, in general occurs and is related to inadequate management practices such as: improper feeding, poor water 
quality, failure of prevention techniques, and a general lack of knowledge on the ecology of these ornamental fish species; while high stocking density and inadequate maintenance of the aquariums are the most common causes of mortality. In addition, external factors such as: inadequate fish transportation, and problems with predators (e.g. birds) and diseases such as: ichthyophthiriasis, lerneosis, fungal and bacterial infections play a part and cause fish mortality. Fungicides with acriflavine base (Aqualife ${ }^{\circledR}$ ) have been used as bactericides, neomycin sulfate base $\left(\right.$ Bacter $\left.^{\circledR}\right)$, and fungicidal drugs such as: methylene blue, malachite green, magnesium sulfate, chloride potassium $\left(\right.$ Ictio $^{\circledR}$ ) and sodium chloride $(\mathrm{NaCl})$ in aquarium shops during quarantine and when problems with parasitosis occur. In addition, on a regular basis, a stabilizer, hydroxymethane sulfinate sodium base (Aquasafe ${ }^{\circledR}$, Prime and Protect $\left.{ }^{\circledR}\right)$, is placed in the aquarium water.

The specimens of $X$. maculatus that were examined had $3.6 \mathrm{~cm} \pm 0.5 \mathrm{~cm}, P$ axelrodi $2.6 \mathrm{~cm} \pm 0.2 \mathrm{~cm}, C$. ephippifer $5.6 \mathrm{~cm} \pm 0.7 \mathrm{~cm}$, and $D$. rerio $3.6 \mathrm{~cm} \pm 0.4 \mathrm{~cm}$ in length. Of 120 fish examined, $22.5 \%(\mathrm{~N}=27)$ were infected by one or more parasite species, and a total of 438 parasites were collected from these hosts. Nematodes Camallanus spp. were found in all hosts species examined and the greater parasitic diversity was among the endoparasite species.

There was a variation in the hosts infected (Table 2) and was found of 2-4 parasite species. Paracheirodon axelrodi was the most parasitized host, while C. ephippifer was the least parasitized host. Ichthyophthirius multifiliis occurred only in $X$. maculatus and $P$. axelrodi, while larvae of Camallanus spp. were found in all examined hosts (Table 3 ).

\section{Discussion}

In four of the ornamental fish species commercialized in Macapá (AP), the parasites community was composed of 8 species: 1 species of protozoan and 7 helminths, totaling 2 ectoparasite species and 6 endoparasite species mainly in the larval stage. These results indicates that such fish are intermediate hosts for the endoparasites found, which were acquired by trophic via. In ornamental fish of aquariums that are commercialized in Florianópolis (Santa Catarina State) the parasites community was composed of 10 species ( 4 protozoans, 1 crustacean, and 5 helminths), totaling 6 species of ectoparasites and 3 of endoparasites (PIAZZA et al., 2006). The difference

Table 1. Ornamental fish species commercialized monthly in 6 major aquarium shops from Macapá, Amapá State, Brazil.

\begin{tabular}{|c|c|c|c|c|}
\hline Common name & Origin & Obtainment & Fish species & Total \\
\hline Goldfish & Non-native & Culture & Carassius auratus Linnaeus, 1758 & 430 \\
\hline Platy fish & Non-native & Culture & Xiphophorus maculatus Günther, 1866 & 350 \\
\hline Green swordtail & Non-native & Culture & Xiphophorus helleri Heckel, 1848 & 915 \\
\hline Molly & Non-native & Culture & Poecilia sphenops Cuvier \& Valenciennes, 1846 & 1,040 \\
\hline Guppy & Native & Culture & Poecilia reticulata Peters, 1859 & 365 \\
\hline Angelfish & Native & Wild & Pterophyllum scalare Schultze in Lichtenstein, 1823 & 135 \\
\hline Cardinal tetra & Native & Wild & Paracheirodon axelrodi Schultz, 1956 & 650 \\
\hline Jewel tetra & Native & Wild & Hyphessobrycon eques Steindachner, 1882 & 70 \\
\hline Spotted gourami & Non-native & Culture & Trichogaster trichopterus Pallas, 1770 & 44 \\
\hline Pencil fish & Native & Wild & Nannostomus eques Steindachner, 1876 & 70 \\
\hline Dwarf gourami & Non-native & Culture & Colisa lalia Hamilton, 1822 & 45 \\
\hline Betta & Non-native & Culture & Betta splendens Regan, 1910 & 105 \\
\hline Zebrafish & Non-native & Culture & Danio rerio Hamilton, 1822 & 960 \\
\hline Oscar & Native & Wild & Astronotus ocellatus Spix \&Agassiz, 1831 & 19 \\
\hline Carp-koi & Non-native & Culture & Cyprinus carpio Linnaeus, 1758 & 214 \\
\hline Tiger barb & Non-native & Culture & Puntius tetrazona Bleeker, 1855 & 80 \\
\hline Saddle corydora & Native & Wild & Corydoras ephippifer Nijssen, 1972 & 40 \\
\hline Total & - & - & & 5,532 \\
\hline
\end{tabular}

Table 2. Distribution frequency of parasites in ornamental fish from Macapá aquarium shops, Amapá State, Brazil.

\begin{tabular}{|c|c|c|c|c|c|}
\hline Host species & Xiphophorus maculatus & Corydoras ephippifer & Danio rerio & Paracheirodon axelrodi & Total \\
\hline \multicolumn{6}{|l|}{ Parasite species } \\
\hline Ichthyophthirius multifiliis & 41 & 0 & 0 & 333 & 374 \\
\hline Monogenea gen. sp. & 3 & 0 & 1 & 0 & 4 \\
\hline Encysted metacercariae & 0 & 0 & 1 & 7 & 8 \\
\hline Diplostomidae (metacercariae) & 0 & 0 & 0 & 2 & 2 \\
\hline Acanthostomum sp. (metacercariae) & 0 & 0 & 0 & 1 & 1 \\
\hline Camallanus spp. (larvae) & 1 & 1 & 19 & 26 & 47 \\
\hline Bothriocephalus acheilognathi & 1 & 0 & 0 & 0 & 1 \\
\hline Echinorhynchus sp. (larvae) & 0 & 1 & 0 & 0 & 1 \\
\hline
\end{tabular}


Table 3. Parasitological indexes in ornamental fish species of aquarium shops from Macapá, Amapá State, Brazil. P: Prevalence, MI: Mean intensity, MA: mean abundance, SD: Standard deviation.

\begin{tabular}{|c|c|c|c|c|c|c|c|c|c|c|c|c|}
\hline \multirow{2}{*}{$\begin{array}{c}\text { Host species } \\
\text { Parasites species }\end{array}$} & \multicolumn{3}{|c|}{ Xiphophorus maculatus } & \multicolumn{3}{|c|}{ Corydoras ephippifer } & \multicolumn{3}{|c|}{ Danio rerio } & \multicolumn{3}{|c|}{ Paracheirodon axelrodi } \\
\hline & $\mathbf{P}(\%)$ & MI & $\mathrm{MA} \pm \mathrm{SD}$ & $\mathbf{P}(\%)$ & MI & $\mathrm{MA} \pm \mathrm{SD}$ & $\mathbf{P}(\%)$ & MI & $\mathrm{MA} \pm \mathrm{SD}$ & $\mathbf{P}(\%)$ & MI & $\mathrm{MA} \pm \mathrm{SD}$ \\
\hline Ichthyophthirius multifiliis & 3.3 & 41.0 & $1.4 \pm 7.5$ & 0 & 0 & 0 & 0 & 0 & 0 & 13.0 & 83.3 & $11.1 \pm 39.9$ \\
\hline Monogenea gen. sp. & 3.3 & 3.0 & $0.1 \pm 0.5$ & 0 & 0 & 0 & 3.3 & 1.0 & $0.03 \pm 0.18$ & 0 & 0 & 0 \\
\hline Encysted metacercariae & 0 & 0 & 0 & 0 & 0 & 0 & 3.3 & 1.0 & $0.03 \pm 0.18$ & 6.7 & 3.5 & $0.2 \pm 1.0$ \\
\hline $\begin{array}{l}\text { Diplostomidae } \\
\text { (metacercariae) }\end{array}$ & 0 & 0 & 0 & 0 & 0 & 0 & 0 & 0 & 0 & 16.7 & 3.0 & $0.87 \pm 2.7$ \\
\hline $\begin{array}{l}\text { Acanthostomum sp. } \\
\text { (metacercariae) }\end{array}$ & 0 & 0 & 0 & 0 & 0 & 0 & 0 & 0 & 0 & 3.3 & 1.0 & $0.07 \pm 0.3$ \\
\hline Camallanus spp. (larvae) & 3.3 & 1.0 & $0.03 \pm 0.2$ & 6.7 & 1.0 & $0.07 \pm 0.25$ & 23.3 & 2.7 & $0.63 \pm 1.56$ & 3.3 & 1.0 & $0.03 \pm 0.2$ \\
\hline Bothriocephalus acheilognathi & 3.3 & 1.0 & $0.03 \pm 0.2$ & 0 & 0 & 0 & 0 & 0 & 0 & 0 & 0 & 0 \\
\hline Echinorhynchus sp. (larvae) & 0 & 0 & 0 & 3.3 & 1.0 & $0.03 \pm 0.18$ & 0 & 0 & 0 & 0 & 0 & 0 \\
\hline
\end{tabular}

in results can be attributed to diverse factors. In general, the presence and transmission of parasites in fish is closely linked to environmental (PIAZZA et al., 2006; GARCIA et al., 2009; MOYSES et al., 2015) and non-environment factors. Water quality parameters in this study had a low variation, thus influencing the reduced appearance of ectoparasite species, which occur mainly in farmed ornamental fish (PIAZZA et al., 2006; GARCIA et al., 2009; KOYUNCU, 2009; MOYSES et al., 2015). The particular characteristics of ornamental fish (e.g. age, physiology, geographic distribution, and feeding habits) are also aspects that may affect the community structure of parasites. These characteristics can make certain potential hosts more susceptible to colonization by new parasites.

The presence and abundance of parasites in ornamental fish species have been mentioned in several studies and parasitism is common and caused by several factors (PIAZZA et al., 2006; KOYUNCU, 2009; TAVARES-DIAS et al., 2010; ABIDI et al., 2011; MOYSES et al., 2015). In this study, 22.5\% of the hosts examined were parasitized and the prevalence was similar to that reported $(34.0 \%)$ for aquarium fish from Florianópolis, Santa Catarina State (PIAZZA et al., 2006). However, the prevalence was lower than that (64.1\%) described for 8 species of ornamental fish captured from the Rio Negro river, Amazonas state (TAVARES-DIAS et al., 2010) and P. axelrodi (65.2\%), which were examined on arrival at the export center in Manaus, Amazonas state (TAVARES-DIAS et al., 2009). Farmed ornamental fish, Xiphophorus spp. had a high parasitism level and was infected by I. multifliis, Trichodina sp., Urocleidoides sp.; and this occurrence was most probably due to inadequate handling and culture practices. There was also a correlation between the intensity of ectoparasites and the parameters of $\mathrm{pH}$, temperature, and electric conductivity of aquarium water (GARCIA et al., 2009). However, in the ornamental fish of this study, the regular use of therapeutic drugs and the moderate levels of salinity found in the aquariums as well as frequent chemotherapy treatments influenced the low levels of ectoparasites found in examined hosts.

Ichthyophthirius multifiliis, which is a protozoan parasite with the greatest worldwide distribution, occurred only in $X$. maculatus and $P$. axelrodi, but the infection was one of the lowest levels of fish examined. Infection levels by I. multifiliis were similar to those described by Piazza et al. (2006), for this same host. Monogenean infections were observed only in $D$. rerio and $X$. maculatus, which had similar levels of parasitism, and were similar to levels reported for $X$. maculatus found in aquariums from Florianópolis (PIAZZA et al., 2006). However, infection levels by monogeneans in $D$. rerio and $X$. maculatus of this study were lower than those found for other farmed and wild ornamental fish species (PIAZZA et al., 2006; TAVARES-DIAS et al., 2009; 2010). This lower value is most probably due to the uses of chemotherapeutics products in the aquariums of the shops herein investigated.

Species digeneans parasites require an intermediate host to complete its life cycle. Snail species are the primary intermediate hosts of these helminths and fish species are the secondary intermediate hosts, while fish-eating birds are the definite hosts (BULLARD \& OVERSTREET, 2008; CARVALHO et al., 2012). Only two species of hosts in this study had digeneans, $P$. axelrodi which was infected by encysted metacercariae, undetermined metacercariae of Diplostomidae and Acanthostomum sp., and D. rerio which was infected by encysted metacercariae at the lowest level of infection. In Brazil, several species of diplostomids are known in fish, but only two species of Acanthostomum Loss are known to infect fish - Acanthostomum gnerii Szidat, 1954 and Acanthostomum spiniceps Loss, 1899 (KOHN et al., 2007).

Camallanus Railliet \& Henry, 1915 (Camallanidae) was found in all hosts examined in this study and had similar levels of infection to those of other studies. Only D. rerio showed higher levels of infection for this nematode. For $X$. maculatus, levels of infections by $C$. maculatus were similar to those of Piazza et al. (2006). In contrast, P. axelrodi had infection levels by Camallanus spp. which were lower than those of Procamallanus sp. described by Tavares-Dias et al. (2009), for this same fish that was maintained in a holding facility of an exporter in Manaus, Amazonas state. In Brazil, ornamental fish have been infected by a non-native nematode Camallanus cotti Fujita, 1927, which infected Poecilia reticulata Peters, 1859 (ALVES et al., 2000). Native nematodes such as Camallanus maculatus Martins, Garcia, Piazza \& Ghiraldelli, 2007 was described infecting $X$. maculatus (MARTINS et al., 2007), Camallanus acaudatus Ferraz \& Thatcher, 1990 infecting Osteoglossum bicirrhosum Cuvier, 1829, and Camallanus tridentatus Drasche, 1884 infecting Arapaima gigas Schinz, 1822 (FERRAZ \& THATCHER, 1990). Few species of Camallanus are known to inhabit South America (FERRAZ \& 
THATCHER, 1990). However, in this study it was not possible to determinate the species of Camallanus due to the low abundance level of these endoparasites. The life cycle of the Brazilian Camallanus species is unknown, but these typically utilize species of copepod for intermediate host and fish as definitive hosts (DE, 1999; ALVES et al., 2000; MARTINS et al., 2007). Therefore, the presence of infected copepods by camallanids in the aquarium shops may be the cause of the presence of these nematodes in hosts. This study is the first report of presence of Camallanus for P. axelrodi, C. ephippifer and Danio rerio.

Bothriocephalus acheilognathi Yamaguti, 1934, a cestode Bothriocephalidea which is originated in Asia and has infected fish on every continent due to the translocation of cyprinids fish. This cestode was found infecting $X$. maculatus at low infection levels similar to those levels reported by Piazza et al. (2006) for undetermined cestodes in X. maculatus, Xiphophorus helleri Heckel, 1848 and Puntius conchonius Hamilton, 1822 in aquariums from Florianópolis, SC. This species of cestode has been considered as an endemic threat and known to cause severe damage in small fish at high infection levels. This cestode has no specificity for hosts; thus, it infects more than 200 fish species around the world (MARCOGLIESE \& ESCH, 1989; BEAN et al., 2007; SALGADO-MALDONADO et al., 2015). Therefore, this Bothriocephalidea clearly has the potential to regulate fish populations. Bothriocephalus acheilognathi utilizes several species of copepods cyclopoids as intermediate hosts, as well as fish, amphibians, reptiles, and birds around the world which could become definitive hosts in potential (MARCOGLIESE \& ESCH, 1989; BEAN et al., 2007; SALGADO-MALDONADO et al., 2015). In South America, B. acheilognathi was introduced in Brazil for the first time through Cyprinus carpio in the 90s. The first record of this non-native cestode was found in C. carpio farmed in the Paraná state, southern Brazil (REGO et al., 1999; SALGADO-MALDONADO et al., 2015). Therefore, this study is the second record of $B$. acheilognathi in fish in Brazil, and the first reporting for $X$. maculatus.

In Brazil, over 60 species of acanthocephalans have been described in freshwater fish, including ornamental fish (LUQUE et al., 2017). Acanthocephalans of genus Echinorhynchus Zoega in Müller, 1776 was found only in the intestine of $C$. ephippifer at low infection levels. However, infection levels of Echinorhynchus spp. were lower than Quadrigyrus nickoli reported for Hyphessobrycon eques, an ornamental fish from Chumucuí River, Pará state (FUJIMOTO et al., 2013). The complex life cycle of Echinorhynchus spp. in freshwater has generally utilized a microcrustacean species as its primary intermediate hosts, and fish as a secondary or definitive hosts (SCHMIDT, 1985; WAYLAND et al., 2015).

As diseases may cause severe morbidity and mortality, which can lead to economic losses in ornamental fish industry, prophylactic treatments should be used when the disease status and the infection source are known (FLORINDO et al., 2017). However, in general, a diagnostic workup of a subsample of the fish is the better method for identifying the problem. In addition, quarantine closely coupled with prophylactic management; the conditioning of ornamental fish during 14-21 days avoids many problems, but generally, this procedure is not practiced. Therefore, quarantine must be a constant procedure in the rearing of aquarium ornamental fish.
A major consideration in maintaining an ornamental fish facility is the disinfection and decontamination of the tanks, aquariums and filters, as well as the whole system. Disinfection protocols can be effective if sufficient investments are made in nets, buckets, and other implements which allow adequate exposure time to disinfectants and well as the extensive rinsing of the tools.

In summary, different native and non-native ornamental fish species were found in aquarium shops from the Macapá (AP). Sanitary conditions observed in the aquarium shops were satisfactory in the reduction of the ectoparasites levels and this was due to the constant prophylactic measures used and the good water quality parameters. However, there was a greater diversity of endoparasites, indicating the presence of infective forms originating in the places of production and/or the fish storage facilities. This demonstrates that the quarantine procedures were not very adequate. Thus, we suggest the need of an adequate quarantine system to minimize spreading of these parasites through commercialization of the fish ornamental. There is a worldwide interest in ornamental fish, and although this has led to development of culture techniques, ornamental fish pathogens are spreading very rapidly due to the high monetary benefits of this trade and the growth of the industry. Failure of prophylactic procedures within any link in the productive chain of ornamental fish can create a native parasite transmission risk as well as the risk of infecting non-native ornamental fish. Therefore, concern about parasitic diseases in ornamental fish is increasing, because breaches in proper biosecurity measures could lead to rapid spread of pathogens.

\section{Acknowledgements}

M. Tavares-Dias was granted (\# 303013/2015-0) a research fellowship from the National Council for Scientific and Technological Development (CNPq, Brazil).

\section{References}

Abidi R, Khan GE, Chauhan UK. Monogenean infestations among freshwater ornamental fishes: an overview. J Ecophysiol Occup Health 2011; 11(3-4): 199-203.

Alves DR, Luque JL, Paraguassú AR, Marques FA. Ocorrência de Camallanus cotti (Nematoda: Camallanidae) parasitando o guppy, Poecilia reticulata (Osteichthyes: Poecilidadae). Rev Univ Rural Ciênc Vida 2000; 22: 77-79.

Bean MG, Škeř́ḱková A, Bonner TH, Scholz T, Huffman DG. First record of Bothriocephalus acheilognathi in the Rio Grande with comparative analysis of ITS2 and V4-18S rRNA gene sequences. J Aquat Anim Health 2007; 19(2): 71-76. PMid:18201046. http://dx.doi.org/10.1577/H06-035.1.

Bullard SAE, Overstreet RM. Digeneans as enemies of fishes. In: Eiras JC, Segner H, Wahli T. Fish diseases. New York: New Hampshire Science Publishers; 2008. p. 817-976.

Bush AO, Lafferty KD, Lotz JM, Shostak AW. Parasitology meets ecology on its own terms: Margolis et al. revisited. J Parasitol 1997; 83(4): $575-$ 583. PMid:9267395. http://dx.doi.org/10.2307/3284227.

Carvalho AR, Azevedo RK, Abdallah VD, Luque JL. Metacercárias de Diplostomidae (Digenea: Diplostomoidea) em Geophagus brasiliensis (Perciformes: Cichlidae) do Rio Guandu, Estado do Rio de Janeiro, 
Brasil. Acta Sci Biol Sci 2012; 34(2): 233-239. http://dx.doi.org/10.4025/ actascibiolsci.v34i2.5957.

De NC. On the development and life cycle of Camallanus anabantis (Nematoda: Camallanidae), a parasite of the climbing perch, Anabas testudineus. Folia Parasitol (Praha) 1999; 46: 205-215.

Eiras JC, Takemoto RM, Pavanelli GC. Métodos de estudo e técnicas laboratoriais em parasitologia de peixes. Maringá: Eduem; 2006.

Faria PMC, Ribeiro K, Almeida CF, Santos FWM, Santos RFB. Aquicultura ornamental: um mercado promissor. Panorama Aquicult 2016; 26: 24-37.

Ferraz EE, Thatcher VE. Camallanus acaudatus sp. n. (Nematoda: Camallanidae) e uma descrição do macho de Camallanus tridentatus (Drasche, 1884), parasitas de peixes da Amazônia Brasileira. Amazoniana 1990; 11(2): 135-145.

Florindo MC, Jerônimo GT, Steckert LD, Acchile M, Figueredo AB, Gonçalves ELT, et al. Metazoan parasites of freshwater ornamental fishes. Lat Am J Aquat Res 2017; 45(5): 992-998. http://dx.doi.org/10.3856/ vol45-issue5-fulltext-15.

Fujimoto RY, Almeida ES, Diniz DG, Eiras JC, Martins ML. First occurrence of Quadrigyrus nickoli (Acanthocephala) in the ornamental fish Hyphessobrycon eques. Rev Bras Parasitol Vet 2013; 22(1): 110-113. PMid:24252956. http://dx.doi.org/10.1590/S1984-29612013000100020.

Garcia F, Fujimoto RY, Martins ML, Moraes FR. Protozoan parasites of Xiphophorus spp. (Poeciliidae) and their relation with water characteristics. Arq Bras Med Vet Zootec 2009; 61(1): 156-162. http://dx.doi.org/10.1590/ S0102-09352009000100022.

Kohn A, Fernandes BMM, Cohen SC. South American trematodes parasites of fishes. Rio de Janeiro: Fi]ocruz; 2007.

Koyuncu CE. Parasites of ornamental fish in Turkey. Bull Eur Assoc Fish Pathol 2009; 29(1): 25-27.

Luque JL, Pereira FB, Alves PV, Oliva ME, Timi JT. Helminth parasites of South American fishes: current status and characterization as a model for studies of biodiversity. J Helminthol 2017; 91(2): 150-164. PMid:27855726. http://dx.doi.org/10.1017/S0022149X16000717.

Marcogliese DJ, Esch GW. Experimental and natural infection of planktonic and benthic copepods by the Asian tapeworm, Bothriocephalus acheilognathi. Proc Helminthol Soc Wash 1989; 56(2): 151-155.

Martins ML, Garcia F, Piazza RS, Ghiraldelli L. Camallanus maculatus n. sp. (Nematoda: Camallanidae) in an ornamental fish Xiphophorus maculatus (Osteichthyes: Poeciliidae) cultivated in São Paulo State, Brazil. Arq Bras Med Vet Zootec 2007; 59(5): 1224-1230. http://dx.doi. org/10.1590/S0102-09352007000500019.

Martins ML, Marchiori N, Roumbedakis K, Lami F. Trichodina nobilis Chen, 1963 and Trichodina reticulata Hirschmann et Partsch, 1955 from ornamental freshwater fishes in Brazil. Braz J Biol 2012; 72(2): 281-286. PMid:22735135. http://dx.doi.org/10.1590/S1519-69842012000200008.

Mehrdana F, Jensen HM, Kania PW, Buchmann K. Import of exotic and zoonotic trematodes (Heterophyidae: Centrocestus sp.) in Xiphophorus maculatus: implications for ornamental fish import control in Europe. Acta Parasitol 2014; 59(2): 276-283. PMid:24827099. http://dx.doi. org/10.2478/s11686-014-0237-z.

Moyses CRS, Spadacci-Morena DD, Xavier JG, Antonucci AM, Lallo MA. Ectocommensal and ectoparasites in goldfish Carassius auratus (Linnaeus, 1758) in farmed in the State of São Paulo. Rev Bras Parasitol Vet 2015; 24(3): 283-289. PMid:26444060. http://dx.doi.org/10.1590/ S1984-29612015054.

Piazza RS, Martins ML, Guiraldelli L, Yamashita MM. Parasitic diseases of freshwater ornamental fishes commercialized in Florianópolis, Santa Catarina, Brazil. Bol Inst Pesca 2006; 32(1): 51-57.

Rego AA, Chubb JC, Pavanelli GC. Cestodes in South American freshwater teleost fishes: keys to genera and brief description of species. Rev Bras Zool 1999; 16(2): 299-367. http://dx.doi.org/10.1590/S010181751999000200003.

Salgado-Maldonado G, Matamoros WA, Kreiser BP, Caspeta-Mandujano JM, Mendoza-Franco EF. First record of the invasive Asian fish tapeworm Bothriocephalus acheilognathi in Honduras, Central America. Parasite 2015; 22: 5. PMid:25654444. http://dx.doi.org/10.1051/parasite/2015007.

Schmidt GD. Development and life cycles. In: Crompton DWT, Nickol BB. Biology of the Acanthocephala. Cambridge: Cambridge University Press; 1985. p. 273-286.

Sommerville C, Endris R, Bell TA, Ogawa K, Buchmann K, Sweeney $\mathrm{D}$. World association for the advancement of veterinary parasitology (WAAVP) guideline for testing the efficacy of ectoparasiticides for fish. Vet Parasitol 2016; 219: 84-99. PMid:27351036. http://dx.doi. org/10.1016/j.vetpar.2015.11.003.

Tavares-Dias M, Brito MLS, Martins ML. Protozoários e metazoários parasitos do cardinal Paracheirodon axelrodi Schultz, 1956 (Characidae), peixe ornamental proveniente de exportador de Manaus, estado do Amazonas, Brasil. Acta Sci Biol Sci 2009; 31(1): 23-28.

Tavares-Dias M, Lemos JRG, Martins ML. Parasitic fauna of eight species of ornamental freshwater fish species from the middle Negro River in the Brazilian Amazon Region. Rev Bras Parasitol Vet 2010; 19(2): 103-107. PMid:20624347. http://dx.doi.org/10.1590/S1984-29612010000200007.

Wayland MT, Vainio JK, Gibson DI, Herniou EA, Littlewood TDJ, Väinölä R. The systematics of Echinorhynchus Zoega in Müller, 1776 (Acanthocephala, Echinorhynchidae) elucidated by nuclear and mitochondrial sequence data from eight European taxa. ZooKeys 2015; 484(484): 25-52. PMid:25829840. http://dx.doi.org/10.3897/zookeys.484.9132. 